\title{
Tolerance Education Through Islamic Religious Education in Indonesia
}

\author{
S. Anwar \\ Ilmu Pendidikan Agama Islam \\ Universitas Pendidikan Indonesia \\ Bandung, INDONESIA \\ saefull@upi.edu
}

\begin{abstract}
- nowadays, social conflicts are still exists and almost founded in every county around The Globe. Even in Indonesia, based on data reported by Mabes Polri, The conflict tends to increase $50 \%$ every year between 2010 and 2013. Therefore, in 2012 government of Indonesia released law of social conflict management No. 7 2012. Generally, the law regulates about prevention, cessation, and recovery after conflict. Based on that regulation, keeping peace in society is one of the best ways to prevent social conflict and the Government should facilitates this among others through strengthening religious education both in schools and society. This paper seeks to provide argumentative review about the importance of Islamic religious education in schools in an effort to instill tolerance in the pupil in Indonesian context.
\end{abstract}

Keywords- Tolerance Education, Religious Education, Islamic Religious Education

\section{INTRODUCTION}

Diversity is an existing reality in life and it can be founded in every single aspect of humanity. Universe, itself, shows us a variation in seasons, times, creatures, and places. Similarly, in our life, we can find many faiths, many tongues, many nations, many communities, many habits, and many cultures. We cannot avoid differences in our life as it is a nature of life and humanity itself. Therefore, we should lesson in diversity and transmit it to our generations.

For Indonesia, diversity is a gift and yet a power as a nation. Indonesia has variety in culture, language, and belief. Base on result of population census 2010 held by Statistics Indonesia (BPS) [1], Indonesia has more than 300 ethnic groups with at least 30 mother tongues and formally 6 religious groups and others faith. With this fact, as Indonesian, we should live in harmony. Indonesian Motto, Unity in Diversity (Bhineka Tunggal Ika) is the philosophy of life.

Unfortunately, in the last five years these facts of diversity become a burden, as a cause of conflict, in Indonesia. Religion conflict in Papua, social conflict in Jakarta and culture conflict in Bali are some of examples. Furthermore, Based on data reported by Mabes Polri, The conflict tends to increase $50 \%$ every year between 2010 and 2013; however, it can be avoided in tolerant society which can be established through education. So, tolerance education is a necessity for Indonesia and religious education in school can be used as a media to teach and instill values of tolerance.

Thus, this paper will discuss about Religious Education (RE), tolerance education (TE), and Islamic Religious Education (IRE) in Indonesian Context.

\section{RELIGIOUS EDUCATION}

\section{A. Defining Religious Education}

Defining something, including RE, is quite difficult. According to Hull, there are many aspects to be considered in constructing a meaning of RE. At least, it depends on the philosophy of education which used, reinterpretation of the term 'religion', the concept of human rights (including the rights of children), the influence of modernity to our life both socially and intellectually, and the development of human maturity concept [2, p. 5]. Thus, we will find different description from every religion scholars when they speak about RE in their country. However, I tried to describe RE in this paper using two approaches, both etymology and terminology.

Etymologically, RE consists of two words: religious and education. Based on Oxford Advanced Learner's Dictionary, the word 'Religious' means something that relate to belief in a religion, whereas 'to educate' means to give knowledge or develop the ability, skill, talent of somebody (student) by teaching. Therefore, religious education implies to teach people about her or his religion.

In modern use, the term 'religion' has plural object. Not only teach about her or his religion but also include the comparison to other religions [3, p. 30].

Terminologically, I present Michael Grimmitt explanation that quoted by John Hull. According to his worldwide survey about RE, there were three types of RE. These types were 'learning religion', 'learning about religion', and 'learning from religion' [2, p. 5].

The first category is 'learning religion'. This kind of RE describe the condition which a single religious tradition becomes a curriculum of RE teaching, where Teacher and student share same religion. For example, the Hindu children are educated by the Hindu teachers; the Muslim children are educated by the Muslim teachers, and so on. The teacher teaches his or her religion concept to assist or strengthen pupil's belief to the religion and their commitment to it. In simple sentence, John Hull described 
it as proceeding from faith to faith which is a religion being taught from inside [2, pp. 5-6].

Another type is 'learning about religion'. This kind of $\mathrm{RE}$ appears as a reaction against 'learning religion' [2, p. 7]. Different from first type, in this type of RE a religion is delivered from the outside as the impact of religious pluralism and religious freedom. Religion was taught as a literature instead a faith. Hence, this kind of RE was known as comparative religion where the subject was named study of religion.

The purpose of 'learning about religion' situation is to promote religious tolerance among student. It qualifies students with critical skill for interpreting religious phenomena and helps them to understand other religious traditions. So, religious intolerance will decrease.

However, according to Hull, this approach of RE has weaknesses [2, p. 7]. It tends to deliver religions as content, instead a value. Thus, it gives little contribution to the life of students in searching for value both moral and spiritual. Consequently, the pupils often have no motivation to learn it.

The third type of RE is 'learning from religion'. Hull concluded that "In the first two kinds of religious education, 'learning religion' and 'learning about religion,' religion is taught for its own sake, whether as an object of faith to which the children are summoned, or as an object worthy of critical study. However, in the third kind, 'learning from religion,' the central focus switches to the children as learners." [2, p. 8] The simple question is what is a role of religion in students life or what can students learn from religion for their life?

Finally, based on three types of RE above, I can argue that it should give many benefits for the shake of students' life. These benefits are comprehensive understanding about their own religion in critical way and good understanding about different religion to promote tolerance attitude.

\section{B. The Aims of Religious Education}

Many religious education scholars have discussed about the purposes of RE. One of them is Deborah Court. She said that the main objectives of $\mathrm{RE}$ is giving religious experience in life of students [4, p. 251]. Other scholars, Haris and Moran stated that RE has two main objectives. These objectives are teaching students to practice their religious way of life, and teaching them to understand religion $[3$, p. 30].

In simple ways, I think there are three points to be considered in RE as its goals: (1) teaching student about religion knowledge; (2) teaching student about being religious (religious awareness); and (3) teaching student to implement religious way or religious values in their daily life. The first point underlines cognitive domain, and the second point stresses affective domain, whereas the last point tensions psychomotor domain. Thus, the combination of three points is the true form of $\mathrm{RE}$ Intention.

\section{TOLERANCE EDUCATION}

\section{A. Meaning of Tolerance Education}

Before defining about tolerance education, at the first we have to point out what does the term of 'tolerance' mean? The word 'tolerance' had attracted many scholars. Among them, D.A. Carson [5] in his book the intolerance of Tolerance had explained it in two ways: the old tolerant and the new tolerance.

The old tolerance means to allow, recognize and respect others' beliefs, practices, etc. without necessarily agreeing or sympathizing. While meaning of the new tolerance advanced one step ahead. It defined as accepting of the differing view of other people, e.g., in religious or political matter, and fairness toward the people who hold these different views. Carson [5, p. 3] said, in the new tolerance, the meaning of tolerance had shifted from accepting the existence of different views to acceptance of different view.

For example, in political matter when a member of a party-political says: "As a statesman, I gladly tolerate other party-political opinion in this problem". In this case, the old meaning of tolerance describes the accepting other party-political opinion without agreeing but the new meaning of tolerance pronounces both accepting and asserting that other opinion from different party-political as valid as his party-political. I think this is what Susanna Palomares [6, p. 1] means that in the parlance of human relations tolerance implies accepting (old tolerance) and something more - underlying respect (new tolerance). But in fact, the two meaning of tolerance still exist in our daily practice.

After clarifying about the word 'tolerance', then we can explore the meaning of tolerance education. Jackman argue that the relationship between tolerance and education is based on hypothesis that democratic values, including tolerance, cannot be developed on their own and these values are to be learned [7]. So, tolerance education means teaching student about tolerance value. In particular, tolerance education is teaching students about diversity. Not only accepting but also respecting that diversity.

\section{B. Purposes of Tolerance Education}

As a part of education goals, tolerance education portrays an important part in developing human's personality. For this reason, Turebayeva calculates tolerance as a quality of a person. Tolerance is an integral characteristic of three components: cognitive, behavioral, and emotional-evaluative. Based on this concept, the purpose or tolerance education is to teach tolerance in those three domains: (1) teaching student knowledge about tolerance and traits or characters of tolerant person (cognitive); (2) teaching student the ability to cooperation at interaction (behavioral); and (3) teaching student about empathy, ability to process of acquisition of knowledge and skills required assess people objectively [8, p. 39].

Other scholar, like Friesenhahn, as quoted by Wallnofer, mentions tolerance education as intercultural theories of education. As intercultural education, tolerance education has the following goals: (1) to deal with multiculturalism in society; (2) to presuppose an inclusive and egalitarian notion of culture, this in turn assumes that all human being and all cultures are equally valid. This is the new tolerance concept; (3) to foster cross culture partnerships and cooperation; (4) to have open attitude to intercultural, political learning; (5) to grow self-conscious about respecting different culture; and (6) to foster peace at the personal and international level $[9$, p. 38]. 
In conclusion, according to Sahin that the main purpose of tolerance education is to help students in developing strategies that will contribute to establish a world order that can provide social justice. In the end it will recognize human honor and the prestige of all mankind, and to respect them all [7, p. 78].

\section{Significant of Tolerance Education}

Tolerance is the desire to establish and maintain positive interactions with people who differ from us by some characteristics or do not adhere to generally accepted opinions [8, p. 39]. For this reason, avoiding intolerant is basic point of tolerance education.

Therefore, I ca see the significant of tolerance education in two ways: (1) diversity is nature of life and human itself. So, as human we can just avoid it. We have to accept, respect, and life with it in harmony. It is the nature of tolerance; and (2) Tolerance is integral and essential to the realization of human rights and the achievement of peace. But, tolerance cannot be taught to individuals directly and they cannot gain this attitude automatically. It has to be taught and practiced in daily life.

\section{ISLAMIC RELIGIOUS EDUCATION AS A MEDIA FOR TOLERANCE EDUCATION: INDONESIAN EXPERIENCE}

\section{A. A Brief History of Religious Education in Indonesia}

In this chapter we will see the history of RE in Indonesia before and after Independence briefly.

1) $R E$ in Indonesia before Independence (Colonial Period)

An educational policy, including religious educationis essentially a political product of a government. As a political product, it highly depends on political will of the government in general [10]. In colonialism era, all policies were focused on strengthening colonialism [11].

In colonial period, both the Dutch and the Japanese, religious education had limited role. The Dutch prohibited the implementation of religious education, explicitly for Islamic Religious Education (IRE), to be taught in all government schools. While in Japanese period, to attract Muslim community in Indonesia as an ally, IRE could be taught in every government schools.

In spite of these limitations, our founding fathers kept struggle for the shake of nation with everything they had. As the result, in the end of Japanese occupation, the preparatory committee for independence in the field of education successfully formulated about the purpose of education. Our first formulation of educational objectives as follows [11]:

"Dalam garis-garis adab perikemanusiaan, seperti terkandung dalam segala pengajaran agama, maka pendidikan dan pengajaran nasional bersendi agama dan kebudayaan bangsa serta menuju ke arah keselamatan dan kebahagiaan masyarakat".

"Based on the principles of humanity, as contained in the teachings of any religion, national education is based on religion and culture of the nation to realize the safety and happiness of society"

Based on the formulation above, religion is a fundamental basis, beside national culture, for national education. This statement becomes important juridical foundation for RE to establish its position and its progress after independence.

\section{2) $R E$ in Indonesia after Independence}

Normatively, the existence of religious education has been recognized, since the beginning of independence. But, at the level of implementation it faced both political and non-political problem. Political problem was regulation support. At that time, no legislation which provided space for the role of religious education and accommodated it in public schools. The government argued that religious education is individual matter and not the responsibility of educational institution like school. On the other hand, non-political obstacles related to socio-cultural and the internal problem of religious education, like curriculum, teachers and learning methods [11].

However, the position of religious education gradually gained established positions and began to recognize formally by the government on December 1946 with the issues of joint regulations between the Minister of Religious Affairs and the Minister of Education and Culture Affairs. The regulation that pointed out that religious education can be taught since grade IV of Sekolah Rakyat (elementary school now) to grade VI optionally with the approval of parents [11]. Finally, based on Education Law of 2003 Number 20, religious education shall be taught at every level of education from primary school to university.

\section{B. Religious Education in Indonesian Education System}

Speaking about position of religious education in the national education system, I would present three national education Acts, there are Education Law of 1954 Number 4, Education Law of 1989 Number 2, and The New Education Law of 2003 Number 20.

\section{1) Education Law of 1950 Number 4}

Education Law of 1950 [12] number 2 was the first Act of Indonesia Education System. In Chapter II, Section 3 of this Act, the purpose of national education is, "establish moral and competent human and democratic and responsible citizens on the welfare of the people and country". The law only regulates education in primary schools. It did no cover regulation about higher education yet. Therefore, we will find deficiencies in some places.

In this Act, religious education is not required to all students. In chapter XII section 20 mentioned that the teaching of religion in all public schools was an option. There were three conditions that a student allowed to enter religious education class, (1) Student minimum grade was fourth; (2) based the will of student and student parent; and (3) religious education does not affect the grade promotion.

On the other hand, this law did not regulate other form of religious education like Pesantren and Madrasah. Thus, both Pesantren and Madrasah as religious education institution played their role independently without government interference.

\section{2) Education Law of 1989 Number 2}

The second education Act, The Law of 1989 Number 2 , stated that religious education as a compulsory subject for all students which was regulated nationally from 
elementary to higher education. Furthermore, religious education placed in the same position with other subjects as stated on chapter IX section 39 [13].

In this Act religious education was integrated in the national education system. In fact, religious education plays an important role, especially to instill moral or character values to students. At least, it was reflected in the statement of national education goals, which to develop students' potentials, namely devout and obedient to The God Almighty, noble, healthy, knowledgeable, capable, creative, independent, and democratic and responsible citizens. Unfortunately, the marginalization of Islamic Education is still founded in this Law, whereas Madrasah and Pesantren regarded as second class.

\section{3) The New Education Law of 2003 Number 20}

This educational Act was born in the frame of education reform agenda. There were at least six points that leads this Law, namely: (1) the demand of equity in education distribution (both quality and quantity) to all regions in Indonesia; (2) low quality of education; (3) the failure of religious education; (4) the increasing number of unemployed educated person; (5) a centralized education system; and (6) local wisdoms that are being abandoned [14]. In general, this legislation was born to enhance on the deficiencies that contained in the National Education Act of 1989 number 2 in the frame of the reform agenda.

This Law gives a wider space for religious education. For example, in article 36-37 about curriculum, it is stated that religious education is a compulsory subject at every level of education from primary school to university. Furthermore, in chapter IV explained that religious education can be organized by both the government and society as a formal, non-formal and informal. Religious education prepares students to be members of the community who understand and practice the values of their religion and or become religious scholars. Finally, Islamic educational institutions, both madrasah and pesantren, have gained recognition from the government and have synchronized with other public education. Thus, with this Act, religious education grows rapidly both quantity and quality. Even Raihani stated that at this time, Islamization in various fields including education managed to find its momentum [15].

\section{Islamic Religious Education as a Part of Religious Education}

One of the rights of students, which guarantee by law, is getting religious education in accordance with their religion and taught by educators who share same religion [16]. In Indonesia school curriculum, there are five groups of subjects. One of these groups is religious and character subject and RE is one of it. Religious subject is a group of subject that teaches about all formal religion in Indonesia and it is based on students' religion. For example, Islamic Religious Education provided for Muslim student, Hindu Religious Education provided for Hindu Student and so on.

\section{Teaching Tolerance through Islamic Religious Education}

In this last chapter, I will argue about teaching tolerance in Islamic Religious Context. What I mean by IRE in this article is a compulsory subject for every Muslim student at each level of education.

\section{1) Meaning of tolerance and tolerance education in} IRE

The meaning of tolerance in Islamic term is accepting diversity as a fact of life. Avoiding this diversity mean avoiding life it self. This concept can be found in The Holy Quran Surah Al-Hujurât ayat 13 as following:

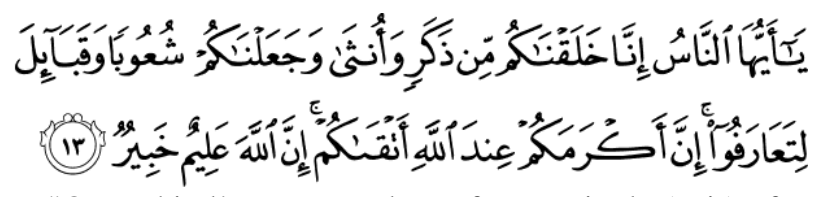

"O mankind! We created you from a single (pair) of a male and a female, and made you into nations and tribes, that ye may know each other (not that ye may despise (each other). Verily the most honoured of you in the sight of Allah is (he who is) the most righteous of you. And Allah has full knowledge and is well acquainted (with all things)" (Q.S. Al Hujurat [49]:13)

That Surah stated, that God created human different in sexes, nations or tribes. With these facts of creation, human is demanded to know each other. God reminded us, that only quality of obedience toward God which made us noble or precious not sex, nation or tribe.

So, tolerant education in term of Islamic Religious Education is a proses of learning diversity in all aspect of humanity to mutual understanding and living in it in harmony.

\section{2) Objectives of tolerance education in IRE}

The objectives of tolerance education in Islamic Religious Education are formulated in two contexts. First, in worshiping term, tolerance education promotes unity in diversity because no matter what your sex, nation or tribe is; we worship the same and only one God. This is the nature of human creation, as mention in the Surah Adz dzariyat:

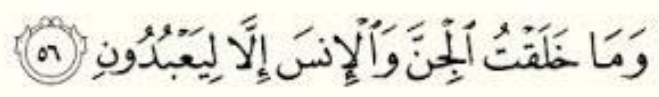

"I have only created Jinns and men, that they may serve Me" (Q.S. Adz Dzariyat [51]:56)

Second, in term of Khalifa, tolerance education promotes, at least three ideas: (1) distribution and management of resources among human beings for the sake of a better life; (2) human perfection lies not in gender, race or ethnicity, but in the ability to collaborate with others to fill shortage of one another and for sure, we will never find perfection in ourselves; and (3) the best human is a man who gave a lot of usefulness to all mankind.

Rasulullah saw said: "A believer acts friendly and there was no goodness for a man who does not act friendly. And the best of men are those who are most beneficial to humans" (HR. Thabrani and Daruquthni)

\section{3) Scope of tolerance education in IRE}

Based on surat Al Hujurat above, I can wrire down three scopes of toleran education in Islamic Religious Education: (1) internal religious tolerance among Muslims who have a different understanding (figh issues); (2) interreligious tolerance. Particularly between Islam and others five formal religions in indonesia; and (3) in general, 
Learning in diversity in Human life (cultures, language, habit, and so on)

\section{4) Method of teaching and learning in tolerance} education

Human beings are learners. Humans were born in a state of knowing nothing. Then, with adult assistance through teaching and individual learning, human starts to get a variety of knowledge which is necessary for life. For this reason Allah SWT said in the surah An Nahl:

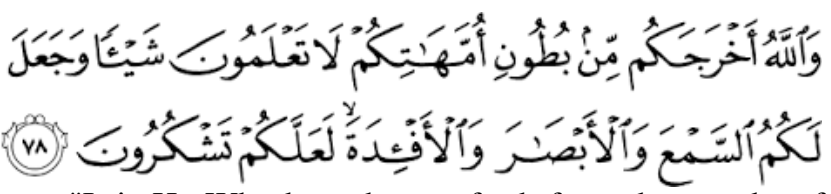

"It is He Who brought you forth from the wombs of your mothers when ye knew nothing; and He gave you hearing and sight and intelligence and affections: that ye may give thanks to Allah" (Q.S. An Nahl [16]: 78)

Based on the Surah above, God gave us three sets of knowledge with which we learn knowledge and or an ability, i.e. hearing, vision, and Fuad [17]. Thus, all knowledge and ability, that we have, were gained through hearing, vision and Fuad. Similarly, to teach tolerance knowledge and ability, we have to empower those elements. The knowledge of tolerance obtained through hearing cognitively; the feeling (emotion side) of tolerance learned through sight affectively; and the act of tolerance learned through Fuad. Fuad is an instrument that gave us the ability to actualize all knowledge that we have through hearing and vision into tangible action in our daily lives.

Finally, tolerance is attitude rather than knowledge. As attitude, the best ways to teach tolerance is repetition, habituation and strengthening. More in

\section{5) Medium in tolerance education}

The best medium for teaching tolerance is a social environment that is enriching and exemplary of teachers of religious education as agents. What I meant by the social environment is family, school, and community. These three, must work together to create a tolerant environment as a living laboratory for students to learn, imitate and practice tolerance. Teachers of religious education as agents must ensure that students have access to the best of the three environments.

\section{CONCLUSION}

Lately, many statements associate intolerance with religion. Even, it came to the conclusion that intolerance has a tendency to grow strongly in the religious community. Furthermore, terrorism as a kind of intolerance was associated with Muslims.

To encounter that false statement, as the biggest Muslim country we can prove that religion and its teaching has significant influence to build tolerance community. Our prophet Muhammad SAW was the life example how build a tolerance community in Madinah based on religious tradition. Therefore, in Indonesia context, Islamic Religious Education can be used as a medium to build that tolerance community.

The best way to build this tolerance community is empowering three social environment to create mutual collaboration as living laboratory. In the end that will enrich student experience in learning, habituating, and practicing tolerance in their daily life.

\section{REFERENCES}

[1] B. P. Statistik, Penduduk Indonesia: Hasil Sensus Penduduk 2010, Jakarta: Badan Pusat Statistik Republik Indonesia, 2012.

[2] J. Hull, "The Contribution of Religious Education to Religious Freedom: A Global Perspective," in "International Consultative Conference on School Education in Relation with Freedom of Religion and Belief, Tolerance, and Non-Discrimination, Madrid, 2002.

[3] M. Harris and G. Moran, Reshaping Religious Education: Conversation on Contemporary Practice, Louisville, Kentucky: Westminster John Knox Press, 1998.

[4] D. Court, "Religious experience as an aim of religious education," British Journal of Religious Education ISSN:, vol. 35, no. 3, pp. 251-263, 2013.

[5] D. A. Carson, The Intolerance of Tolerance, Michigan: William B. Eerdmans Publishing Company, 2012.

[6] S. Palomares, Lessons in Tolerance and Diversity, D. Schilling, Ed., Wellington: Innerchoice Publishing, 2009.

[7] C. Sahin, "Perceptions of Prospective Teachers about Tolerance Education," Educational Research and Reviews, vol. 6, no. 1, pp. 77-86, 2011

[8] C. Z. Turebayeva, S. Y. Doszhanova, Z. O. Orazova and B. T. Zhubatyrova, "Education of Tolerant Personality of a Future Specialist as the Social-Pedagogical Phenomenon," Middle-East Journal of Scientific Research, vol. 13, pp. 38-42, 2013.

[9] W. Gerwald, "Tolerance, Religion and Education," in Tolerance and Education in Multicultural Societies, W. Wiater and D. Manschke, Eds., Frankfurt am Main, Peter Lang, 2011, pp. 37-44.

[10] A. Abdullah, "Pendidikan Islam Sepanjang Sejarah : Sebuah Kajian Politik Pendidikan di Indonesia," Susurgalur: Jurnal Kajian Sejarah \& Pendidikan Sejarah, vol. 1, no. 2, pp. 213-228, 2013.

[11] T. Hamami, "Pendidikan Agama Islam di Sekolah Umum sebagai Keharusan Sejarah," Jurnal Pendidikan Agama Islam, vol. 1, no. 2, pp. 171-191, 2004

[12] D. P. Nasional, Undang-Undang No. 4 Tahun 1950 tentang Dasar Pendidikan dan Pengadjaran di Sekolah.

[13] D. P. Nasional, Undang Undang No. 2 Tahun 1989 tentang Sistem Pendidikan Nasional.

[14] Irham, "Pesantren dan Perkembangan Politik Pendidikan Agama di Indonesia," Jurnal Taklim, vol. 13, no. 1, pp. 93-118, 2015.

[15] Raihani, "A whole-school approach: A proposal for education for tolerance in Indonesia," Theory and Research in Education, vol. 9, no. 1, pp. 23-39, 2011.

[16] D. P. Nasional, Undang-Undang No. 20 Tahun 2003 tentang Sistem Pendidikan Nasional.

[17] Y. Qardhawi, Alquran berbicara tentang Akal dan Ilmu Pengetahuan, Jakarta: Bandung, 1998. 